\title{
Predictors of cardiovascular risk in a population of diabetic adults of Gypsy origin, in Granada
}

\author{
Hernandez-PerezdelaBlanca $\mathrm{M}^{1}$, Rebora-Mariano $\mathrm{T}^{1}$, Ramirez-Robles $\mathrm{R}^{1}$, Berna-Guisado $\mathrm{C}^{2}$, \\ Vides-Batanero $\mathrm{MC}^{1}$, Castro-Gomez $\mathrm{JA}^{1}$
}

Centro de salud Almanjayar. Servicio Andaluz de Salud, Spain. mercedeshpb@hotmail.com

\begin{abstract}
Aims: The aim of this work is to identify cardiovascular risk factors in a population of ethnic Gypsy diagnosed with type 2 diabetes mellitus (T2DM) and to compare this population with a control group of nonGypsy patients also diagnosed with T2DM and with a similar sociological background.

Design: Observational descriptive cross-cutting study.

Methods: Using a systematic random sampling, we selected a sample of 220 Gypsy patients diagnosed with T2DM and another sample of 230 non-Gypsy patients, also diagnosed with T2DM. Both samples were composed of patients registered at the Almanjáyar and Cartuja health centres, in Granada (Spain). The data were collected between October 2010 and October 2011.

Results: There were statistically significant differences between the Gypsy and non-Gypsy patients in the following variables concerning the control of cardiovascular risk: systolic blood pressure, diastolic blood pressure, HDL cholesterol, triglycerides and cardiovascular risk.

Conclusions: The factors of cardiovascular risk presented by Gypsy patients diagnosed with T2DM were more acute than those of non-Gypsy patients (Tab. 7, Ref. 26). Text in PDF www.elis.sk.

Key words: Gypsy, cardiovascular risk factors, diabetes mellitus, gender, ethnicity.
\end{abstract}

Diabetes mellitus is considered a major health problem in the developed world, due to its prevalence, its economic cost and the number of premature deaths caused. From a clinical viewpoint, it is composed of a heterogeneous set of processes whose common characteristic is the hyperglycaemia (high blood sugar) resulting from defects in insulin secretion, usually by the autoimmune-mediated destruction of pancreatic beta cells (in diabetes mellitus type 1 , T1DM), or due to progressive resistance to the peripheral action of insulin, with or without secretory deficit (in T2DM) (1). $90 \%$ of diabetics are type 2 (2) and the prevalence of T2DM is increasing worldwide. In developed countries, it is coming to be one of the most common chronic diseases (3), mainly due to its relation with obesity and aging. It can cause serious complications including heart disease, stroke, blindness, kidney failure, lower limb amputation, disability and premature death $(4,5,6,7,8)$ with cardiovascular disease (9) being the most common complication and most frequent cause of death for $50-70 \%$ (10) of the diabetic population $(11,12,13)$.

Some studies have reported a relationship between socioeconomic status and the frequency of chronic diseases such as DM $(14,15,16)$.

According to some studies, the prevalence of T2DM appears to be higher among the Gypsy population $(17,18,19)$, and other studies have reported an increased cardiovascular risk in this population

${ }^{1}$ Centro de salud Almanjayar, Servicio Andaluz de Salud, Spain, and ${ }^{2}$ Centro de salud Cartuja, Servicio Andaluz de Salud, Spain

Address for correspondence: $\mathrm{M}$. Hernandez-PerezdelaBlanca, Dr, Calle Pintor Fernando Belda, 62, Blq. 2, 8-B, 18015-Granada, Spain.
$(20,21,22)$. As long ago as 1987, The Lancet published a small-scale study that reported a high prevalence of diabetes, obesity, dyslipidaemia and hypertension among 58 Gypsy living in Boston (USA) (23).

In Spain, the Gypsy population is the largest ethnic minority (24) with a total population of 650,000, of whom 250,000 live in the southern region of Andalusia (25). The dietary customs of the Gypsy population have changed dramatically in recent decades, and current rates of obesity are very high, due to the consumption of large proportions of low-protein, high-calorie food (26). In Andalusia, most members of this ethnic group live in towns and cities, and are integrated with the rest of the population. However, in Spain, little research has been carried out into cardiovascular risk and the degree of metabolic control among diabetics in the Gypsy population. Therefore, the present study may be of interest in this respect.

The aim of this study is to determine the prevalence of predictors of cardiovascular disease in adult diabetics among the Gypsy population, and to evaluate the degree of metabolic control achieved. For this purpose, we carried out a comparative study, with a group of non-Gypsy patients diagnosed with T2DM and belonging to a very similar socio-economic environment. We believe, therefore, that any significant differences found can reasonably be attributed to the patients' ethnic origin.

\section{Methods}

In the region of Andalusia, in southern Spain, the public healthcare system is based upon primary health clinics where citizens may register. The reference population for the present study cor- 
responded to two districts of the city of Granada (in SE Andalusia). The data used in this study were obtained from the Diraya computerised database, which contains the medical records of all patients registered with the Andalusian Health Service. The study population was comprised of all the diabetic patients in the above-mentioned districts who were diagnosed and registered in the Diraya system, a total of 1,584 diabetics.

The necessary sample size was considered to be 172 diabetics per ethnic group, a value increased to 200 in anticipation of possible losses or errors in the registration system. This figure was arrived at taking into account a statistical power of $80.0 \%$ to detect differences between groups, a confidence level of $95 \%$ and an alpha error of $5 \%$, assuming (from previously published data) a prevalence of arterial hypertension of $47.5 \%$ among the non-Gypsy and of $62.5 \%$ among the Gypsy groups (and differences of at least $15 \%$ in the major cardiovascular risk factors).

To formulate the two groups of diabetics, and in view of the sample size needed for each group, we selected all the Gypsy diabetics (220) and then carried out systematic sampling from the list of non-Gypsy diabetics with a sampling fraction of six and an initial random start point, thus producing a total of 230 patients. Of these, 14 were lost to the study.

Each patient was assigned an identification number and was classified in accordance with the following 22 variables.

General: Gender (male/female, henceforth M-F), Ethnicity (Gypsy/non-Gypsy, R-NR), body mass index $\left(\mathrm{kg} / \mathrm{m}^{2}\right.$ ) (BMI), age in 2012 and age at the time of diagnosis with T2DM.

Cardiovascular risk: Tobacco consumption (non-smoker/ smoker) and diagnosis of arterial hypertension (presence/absence).

Vascular disease: Cerebrovascular accident (CVA) (presence/ absence), nephropathy (presence/absence), retinopathy (presence/ absence), ischaemic heart disease (presence/absence), and lower limb complications (LLC) (presence/absence).

Control of cardiovascular risk: Systolic blood pressure (SBP) (mmHg), diastolic blood pressure (DBP) (mmHg), glycosylated haemoglobin (HbA1c) (\%), total cholesterol (mg/dl), HDL cholesterol (HDL- $)$ (mg/dl), LDL cholesterol (LDL- $)$ (mg/dl), triglycerides (mg/dl), urea (mg/dl), creatinine (mg/dl), and cardiovascular risk (CVR) according to the Framingham method (\%).

The epidemiological design used to meet the study targets was that of a descriptive cross-cutting observational study and the time period for measuring the study variables was 12 months, from 31 October 2010 to 31 October 2011.

We wished to compare certain magnitudes between Gypsy and non-Gypsy patients. In many of the variables considered there was also a significant difference between men and women and so the gender factor was taken into consideration in constructing the subgroups. Taking the above into account, a statistical analysis was made of the following nine populations. Table 1 shows the nine populations.

Tab. 1. Sample classification by ethnic group and gender.

\begin{tabular}{lccc}
\hline & Non Roma & Roma & Total \\
\hline Male & $89(44.7 \%)(\mathrm{M} \& N R)$ & $110(55.3 \%)(\mathrm{M} \& R)$ & $199(100 \%)(\mathrm{M})$ \\
Female & $123(51.9 \%)(\mathrm{F} \& N R)$ & $114(48.1 \%)(\mathrm{F} \& \mathrm{R})$ & $237(100 \%)(\mathrm{F})$ \\
\hline Total & $212(48.6 \%)(\mathrm{NR})$ & $224(51.4 \%)(\mathrm{R})$ & $436(100 \%)(\mathrm{T})$ \\
\hline
\end{tabular}

For the quantitative variables present in the database, we analysed a series of descriptive statistics to obtain a general overview (not included in the text), using $95 \%$ confidence intervals for the mean of the corresponding variable (some cases included in the text). The most important was the comparison of the different populations to determine whether there are significant differences among them. This was done using the MannWhitney nonparametric tests of homogeneity (the corresponding $\mathrm{p}$-value is given as $\mathrm{p}_{1}$ ). T-tests were also applied to determine the equality of the means ( $\mathrm{p}$-value given as $\mathrm{p}_{2}$ ). When a significant difference between the means was observed, a $95 \%$ confidence interval was constructed for this difference. For the qualitative variables, the most important aspect for the present study is the comparison of populations to establish the existence or otherwise of significant differences. For this purpose, chi-square tests were performed for contingency tables (the corresponding p-value is given as $\mathrm{p}_{3}$ ). All statistical analysis was performed using SPSS 17.0 Software.

\section{Results and discussion}

\section{General variables}

With respect to the age of the patient in 2012, Table 2 shows the mean, the range containing the central $90 \%$ of the data and the confidence interval for the mean value, for each population.

\section{Tab. 2. Age in 2012.}

\begin{tabular}{lccc}
\hline Population & Mean & Range* $^{*}$ & 95\% CI for the mean \\
\hline $\mathrm{T}$ & 63.30 & 38.15 & $(62.15 ; 64.24)$ \\
$\mathrm{M}$ & 62.15 & 37.00 & $(60.51 ; 63.78)$ \\
$\mathrm{F}$ & 64.26 & 39.10 & $(62.66 ; 65.86)$ \\
$\mathrm{R}$ & 60.36 & 37.00 & $(58.86 ; 61.86)$ \\
$\mathrm{NR}$ & 66.40 & 38.70 & $(64.74 ; 68.06)$ \\
M\&R & 60.23 & 38.45 & $(58.04 ; 62.41)$ \\
M\&NR & 64.52 & 37.50 & $(62.09 ; 66.95)$ \\
F\&R & 60.48 & 39.25 & $(58.40 ; 62.57)$ \\
F\&NR & 67.76 & 40.60 & $(65.50 ; 70.03)$ \\
\hline
\end{tabular}

*The range shown is the 95th percentile less the 5th percentile, in order to avoid the influence of outliers.

For the variable Age of the patient in 2012 there were significant differences in terms of ethnicity $\left(\mathrm{p}_{1}=0.00, \mathrm{p}_{2}=0.00\right)$. The average age of the NR population was higher than that of the $\mathrm{R}$ population and the $95 \%$ CI for the difference of the means was (3.82; 8.27). Within the male population, the corresponding values for M\&NR were also higher than for $M \& R\left(p_{1}=0.01, \mathrm{p}_{2}=\right.$ 0.01 ), and the $95 \% \mathrm{CI}$ for the difference of the means was (1.04; 7.54). Among the female population, the mean age for F\&NR was higher than for F\&R $\left(p_{1}=0.00, p_{2}=0.00\right)$, with a $95 \%$ CI for the difference of the means of $(4.21 ; 10.36)$. When comparing the $\mathrm{M}$ and $\mathrm{F}$ populations within the total population $\mathrm{T}$, we obtained $\mathrm{p}_{1}=$ 0.10 and $\mathrm{p}_{2}=0.07$. This was more pronounced in the comparison of $\mathrm{M}$ and $\mathrm{F}$ within the NR population, producing values of $\mathrm{p}_{1}=$ 0.04 and $\mathrm{p}_{2}=0.05$.

There was a significant difference in patient age at diagnosis of T2DM according to ethnicity: in the total population, between NR and $R\left(p_{1}=0.00, p_{2}=0.00\right)$, the average age of the NR population was higher and the $95 \%$ CI for the difference of the means 
was (3.93; 8.26). This difference persisted for both sexes; in the $\mathrm{M}$ population there was a significant difference between NR and $\mathrm{R}$ $\left(p_{1}=0.02, p_{2}=0.01\right)$; the mean age of the NR was higher, and the $95 \%$ CI for the difference of the means was $(0.96 ; 7.22)$. Within the $\mathrm{F}$ population, there was a significant difference between NR and $\mathrm{R}\left(\mathrm{p}_{1}=0.00, \mathrm{p}_{2}=0.00\right)$; the mean age of the NR was greater, and the $95 \% \mathrm{CI}$ for the difference of the means was $(4.65 ; 10.68)$.

For $90 \%$ of the sample population, the BMI was above 25.61 . In $25 \%$ of this population, it was above 35.95 and in $10 \%$, above 41.73. Table 3 shows the mean, the 5 th percentile (95\% of the observations were above this value), the range encompassing the central $90 \%$ of the observations and the confidence intervals for the mean BMI in the different populations.

Tab. 3. Body mass index.

\begin{tabular}{lcccc}
\hline Population & Mean & 5th percentile & Range* $^{*}$ & 95\% CI for the mean \\
\hline $\mathrm{T}$ & 33.02 & 24.38 & 21.54 & $(32.371 ; 33.660)$ \\
$\mathrm{M}$ & 31.82 & 24.44 & 17.65 & $(31.063 ; 32.594)$ \\
$\mathrm{F}$ & 33.99 & 24.14 & 24.19 & $(33.011 ; 34.967)$ \\
$\mathrm{R}$ & 33.94 & 24.99 & 24.06 & $(32.964 ; 34.924)$ \\
$\mathrm{NR}$ & 32.06 & 23.80 & 20.00 & $(31.236 ; 32.874)$ \\
M\&R & 32.56 & 25.22 & 16.93 & $(31.546 ; 33.566)$ \\
M\&NR & 30.95 & 23.73 & 18.94 & $(29.790 ; 32.119)$ \\
F\&R & 35.24 & 24.51 & 28.13 & $(33.619 ; 36.866)$ \\
F\&NR & 32.84 & 23.81 & 20.63 & $(31.718 ; 33.965)$ \\
\hline
\end{tabular}

The range shown is the 95th percentile less the 5th percentile, in order to avoid the influence of outliers

Significant differences in BMI were observed according to ethnicity and gender. By ethnicity, the mean BMI among the NR population was lower $\left(\mathrm{p}_{1}=0.01, \mathrm{p}_{2}=0.00\right)$ and the $95 \% \mathrm{CI}$ for the difference of the means was $(-3.17 ;-0.61)$. This difference persisted within the M population, where the BMI was lower among the M\&NR population $\left(\mathrm{p}_{1}=0.01, \mathrm{p}_{2}=0.04\right)$ and the $95 \% \mathrm{CI}$ for the difference of the means was $(-3.13 ;-0.08)$. This was also the case within the F population, where the BMI of the F\&NR was lower $\left(\mathrm{p}_{1}=0.07, \mathrm{p}_{2}=0.02\right)$ and the $95 \%$ CI for the difference of the means was $(-4.34 ;-0.46)$. By gender, the BMI was lower among the $\mathrm{M}$ population $\left(\mathrm{p}_{1}=0.01, \mathrm{p}_{2}=0.00\right)$ and the $95 \% \mathrm{CI}$ for the difference of the means was $(-3.44 ;-0.88)$.

\section{Variables related to cardiovascular risk}

Table 4 shows the frequency for the Tobacco consumption variable and for the variable reflecting the diagnosis of arterial hypertension (AHT).

Tab. 4. Tobacco consumption: frequencies.

\begin{tabular}{|c|c|c|c|c|c|}
\hline & \multicolumn{5}{|c|}{ Population } \\
\hline & $\mathrm{T}$ & $\mathrm{R}$ & NR & $\mathrm{M}$ & $\mathrm{F}$ \\
\hline Smoker & 24.7 & 30.50 & 18.60 & 32.70 & 17.90 \\
\hline Non-smoker & 75.3 & 69.50 & 81.40 & 67.30 & 82.10 \\
\hline Total & 100 & 100 & 100 & 100 & 100 \\
\hline \multicolumn{6}{|c|}{ Diagnosis of AHT: frequencies } \\
\hline & \multicolumn{5}{|c|}{ Population } \\
\hline & $\mathrm{T}$ & $\mathrm{R}$ & NR & $\mathrm{M}$ & $\mathrm{F}$ \\
\hline Yes & 74.7 & 78.60 & 70.50 & 71.07 & 77.64 \\
\hline No & 25.5 & 21.40 & 29.50 & 28.93 & 22.36 \\
\hline Total & 100 & 100 & 100 & 100 & 100 \\
\hline
\end{tabular}

It can be seen that approximately three quarters of the sample population were diagnosed with AHT.

For the variable Tobacco consumption there were significant differences in almost all cases: in the total population between $\mathrm{R}$ and NR $\left(\mathrm{p}_{3}=0.01\right)$, with the highest frequency being found in the $\mathrm{R}$ population; between $\mathrm{M}$ and $\mathrm{F}\left(\mathrm{p}_{3}=0.00\right)$. Within the $\mathrm{R}$ population there were significant differences between the $\mathrm{M}$ and F populations $\left(\mathrm{p}_{3}=0.00\right)$, and among the $\mathrm{M}$ population, between the NR and $\mathrm{R}$ populations $\left(\mathrm{p}_{3}=0.05\right)$.

For the variable Diagnosis of AHT, there were significant differences by ethnicity: in the total population between NR and R $\left(\mathrm{p}_{3}=0.05\right)$, where the highest frequency was observed in the $\mathrm{R}$ population; and in the F population, there was a significant difference between $\mathrm{NR}$ and $\mathrm{R}\left(\mathrm{p}_{3}=0.04\right)$.

\section{Variables related to vascular disease}

For the variables related to vascular disease, the following frequencies of presence or absence were observed (Tab. 5).

Tab. 5. Variables of vascular disease: frequencies.

\begin{tabular}{|c|c|c|c|c|c|c|}
\hline \multirow{2}{*}{ Variables } & & \multicolumn{5}{|c|}{ Population } \\
\hline & & $\mathrm{T}$ & $\mathrm{R}$ & NR & $M$ & $\mathrm{~F}$ \\
\hline \multirow{2}{*}{$\begin{array}{l}\text { Cerebrovascular } \\
\text { accident }\end{array}$} & YES & 5.80 & 6.25 & 5.26 & 6.63 & 5.06 \\
\hline & NO & 94.20 & 93.75 & 94.74 & 93.37 & 94.94 \\
\hline \multirow{2}{*}{$\begin{array}{l}\text { Ischaemic heart } \\
\text { disease }\end{array}$} & YES & 10.60 & 11.61 & 9.57 & 14.80 & 7.17 \\
\hline & NO & 89.40 & 88.39 & 90.43 & 85.20 & 92.83 \\
\hline \multirow[t]{2}{*}{ Nephropathy } & YES & 18.90 & 18.52 & 19.21 & 21.99 & 16.23 \\
\hline & NO & 81.10 & 81.48 & 80.79 & 78.01 & 83.77 \\
\hline \multirow[t]{2}{*}{ Retinopathy } & YES & 17.10 & 18.44 & 15.76 & 17.26 & 16.92 \\
\hline & NO & 82.90 & 81.56 & 84.24 & 82.74 & 83.08 \\
\hline \multirow{2}{*}{$\begin{array}{l}\text { Lower limb } \\
\text { complications }\end{array}$} & YES & 8.10 & 10.30 & 5.80 & 7.70 & 8.50 \\
\hline & NO & 91.90 & 89.70 & 94.20 & 92.30 & 91.50 \\
\hline
\end{tabular}

For cerebrovascular accident (5.80 \%), nephropathy (18.90\%) and retinopathy $(17.10 \%)$ there were no significant differences among the subpopulations considered.

Ischaemic heart disease was observed in $10.60 \%$ of the total population. For this variable, the following differences were observed: in the total population, between $\mathrm{M}$ and $\mathrm{F}\left(\mathrm{p}_{3}=0.01\right)$, with a higher frequency of disease in $\mathrm{M}$ than in $\mathrm{F}$. In the NR population, there was a significant difference between the $\mathrm{M}$ and $\mathrm{F}$ populations $\left(\mathrm{p}_{3}=0.02\right)$.

Lower limb complications were observed in $8.10 \%$ of the total population. In the latter $\left(\mathrm{p}_{3}=0.08\right)$, the $\mathrm{R}$ population presented a frequency of $10.30 \%$ versus $5.80 \%$ in the NR population. In the $\mathrm{M}$ population, there were significant differences between the NR and R populations $\left(\mathrm{p}_{3}=0.01\right)$; thus, lower limb complications were present in $2.3 \%$ of M\&NR versus $11.8 \%$, five times higher, among M\&R.

Variables related to the degree of control of cardiovascular risk

The following two tables show the $95 \%$ confidence intervals for the mean, for each of the populations examined (Tabs 6 and 7).

For SBP, the mean value for NR was lower than for $\mathrm{R}\left(\mathrm{p}_{1}=\right.$ $0.01, \mathrm{p}_{2}=0.01$ ) and the $95 \% \mathrm{CI}$ for the difference of the means was $(-7.82 ;-1.15)$. Among the F population, F\&NR was lower than $F \& R\left(P_{1}=0.04, P_{2}=0.05\right)$ and the $95 \% \mathrm{CI}$ for the difference of the means was $(-8.9 ; 0.1)$. 
Tab. 6. Variables affecting control of cardiovascular risk: $95 \%$ CI for the mean.

\begin{tabular}{|c|c|c|c|c|c|}
\hline \multirow{2}{*}{ Populations } & \multicolumn{5}{|c|}{ Variable } \\
\hline & SBP & DBP & HbA1c & Creatinine & CVR \\
\hline $\mathrm{T}$ & $(129.57 ; 135.12)$ & $(75.53 ; 78.71)$ & $(7.685 ; 8.151)$ & $(0.831 ; 0.924)$ & $(19.20 ; 21.97)$ \\
\hline $\mathrm{M}$ & $(126.52 ; 135.58)$ & (75.32; 80.43) & (7.342; 8.110) & $(0.868 ; 1.029)$ & $(22.43 ; 26.87)$ \\
\hline $\mathrm{F}$ & $(129.75 ; 136.80)$ & (74.52; 78.63) & $(7.763 ; 8.348)$ & $(0.774 ; 0.881)$ & $(16.09 ; 19.25)$ \\
\hline $\mathrm{R}$ & $(129.73 ; 137.93)$ & (77.37; 80.96) & (7.615; 8.324) & $(0.808 ; 0.922)$ & $(19.43 ; 23.34)$ \\
\hline NR & $(126.99 ; 134.47)$ & (73.26; 77.62) & (7.560; 8165) & $(0.818 ; 0.966)$ & $(17.74 ; 21.69)$ \\
\hline M\&R & $(126.40 ; 139.90)$ & (75.11; 82.85) & (7.236; 8.373) & $(0.822 ; 0.978)$ & $(21.91 ; 28.36)$ \\
\hline M\&NR & $(122.42 ; 134.15)$ & (73.24; 79.62) & (7.111; 8.134) & $(0.854 ; 1.169)$ & $(20.94 ; 27.09)$ \\
\hline F\&R & $(129.21 ; 139.59)$ & $(75.57 ; 81.23)$ & $(7.648 ; 8.566)$ & $(0.752 ; 0.919)$ & $(16.13 ; 20.37)$ \\
\hline F\&NR & $(127.27 ; 137.14)$ & (71.87; 77.82) & (7.625; 8.388) & $(0.750 ; 0.889)$ & $(14.73 ; 19.52)$ \\
\hline
\end{tabular}

Tab. 7. Variables affecting control of cardiovascular risk (contd.): $95 \%$ CI for the mean.

\begin{tabular}{|c|c|c|c|c|}
\hline \multirow{2}{*}{ Population } & \multicolumn{4}{|c|}{ Variables } \\
\hline & Cholesterol & HDL cholesterol & LDL cholesterol & Triglycerides \\
\hline $\mathrm{T}$ & $(192.28 ; 205.69)$ & (39.83; 43.18) & $(108.72 ; 118.60)$ & $(216.20 ; 269.12)$ \\
\hline $\bar{M}$ & $(178.52 ; 199.63)$ & (35.44; 39.26) & $(99.46 ; 112.07)$ & $(212.10 ; 313.18)$ \\
\hline $\mathrm{F}$ & $(197.51 ; 214.67)$ & $(42.09 ; 46.88)$ & $(112.25 ; 126.38)$ & $(201.38 ; 251.98)$ \\
\hline $\mathrm{R}$ & $(186.85 ; 206.83)$ & (37.09; 40.75) & $(103.99 ; 117.89)$ & $(222.81 ; 305.03)$ \\
\hline NR & $(192.30 ; 210.32)$ & $(41.52 ; 47.10)$ & $(109.52 ; 123.71)$ & $(188.10 ; 251.88)$ \\
\hline M\&R & $(170.78 ; 199.74)$ & (32.93; 37.15) & $(94.06 ; 111.02)$ & $(197.03 ; 314.97)$ \\
\hline M\&NR & $(178.10 ; 210.08)$ & $(37.07 ; 43.67)$ & $(100.29 ; 119.71)$ & $(182.46 ; 320.86)$ \\
\hline F\&R & $(192.87 ; 220.18)$ & $(39.56 ; 44.77)$ & $(107.48 ; 128.45)$ & $(212.34 ; 303.66)$ \\
\hline F\&NR & $(194.69 ; 216.65)$ & $(42.73 ; 50.65)$ & $(110.78 ; 130.42)$ & $(170.32 ; 231.44)$ \\
\hline
\end{tabular}

For DBP, NR was lower than $\mathrm{R}\left(\mathrm{p}_{1}=0.00, \mathrm{p}_{2}=0.00\right)$ and the $95 \%$ CI for the difference of the means was $(-5.75 ;-1.70)$. In the $\mathrm{M}$ population, $\mathrm{M} \& \mathrm{NR}$ was lower than $\mathrm{M} \& \mathrm{R}\left(\mathrm{p}_{1}=0.03, \mathrm{p}_{2}=\right.$ 0.04 ) and the $95 \%$ CI for the difference of the means was (-6.33; -0.1), while among the F population, F\&NR was lower than F\&R $\left(p_{1}=0.01, p_{2}=0.00\right)$ and the $95 \%$ CI for the difference of the means was $(-6.7 ;-1.3)$.

For HbA1c, there were no differences with respect to ethnicity. Among the total population, the nonparametric tests revealed a difference with respect to gender $\left(p_{1}=0.03\right)$. In the NR population the difference between the $\mathrm{M}$ and $\mathrm{F}$ populations was significant $\left(\mathrm{p}_{1}=0.01, \mathrm{p}_{2}=0.05\right)$ and the $95 \%$ CI for the difference of the means was $(--0.93 ; 0)$.

For urea, no significant differences were found among the various subpopulations.

For creatinine, there were no significant differences by ethnicity. By contrast, there was a significant difference by gender; the value for the $\mathrm{M}$ population was higher than that for $\mathrm{F}\left(\mathrm{p}_{1}=0.00\right.$, $\mathrm{p}_{2}=0.00$ ) and the $95 \% \mathrm{CI}$ for the difference of the means was $(0.06 ; 0.18)$. This difference persisted in each of the two ethnic groups; in the $\mathrm{R}$ population, $\mathrm{M} \& \mathrm{R}$ was higher than $\mathrm{F} \& \mathrm{R}\left(\mathrm{p}_{1}=\right.$ $\left.0.00, \mathrm{p}_{2}=0.05\right)$ and the $95 \% \mathrm{CI}$ for the difference of the means was $(0 ; 0.17)$, and in the NR population, M\&NR was higher than $\mathrm{F} \& N R\left(\mathrm{p}_{1}=0.00, \mathrm{p}_{2}=0.00\right)$ and the $95 \% \mathrm{CI}$ for the difference of the means was $(0.07 ; 0.24)$.

With respect to cardiovascular risk, there was a gender difference; the value for the $\mathrm{M}$ population was higher than for $\mathrm{F}\left(\mathrm{p}_{1}=\right.$ $0.00, \mathrm{p}_{2}=0.00$ ) and the $95 \% \mathrm{CI}$ for the difference of the means was (3.8; 7.4). This gender difference persisted in the ethnicity analysis.
In the $\mathrm{R}$ population, $\mathrm{M} \& \mathrm{R}$ was higher than $\mathrm{F} \& \mathrm{R}\left(\mathrm{p}_{1}=0.00, \mathrm{p}_{2}=\right.$ 0.00 ) and the $95 \% \mathrm{CI}$ for the difference of the means was (3.4; 8.6). In the NR population, $M \& N R$ was higher than $F \& N R\left(\mathrm{p}_{1}=\right.$ $0.00, \mathrm{p}_{2}=0.00$ ) and the $95 \% \mathrm{CI}$ for the difference of the means was $(2.4 ; 7.4)$. It is noteworthy that there was considerable evidence of difference by ethnicity $\left(\mathrm{p}_{1}=0.08, \mathrm{p}_{2}=0.05\right)$ and the 95 $\%$ CI for the difference of the means was $(-3.71 ; 0.02)$ (Tab. 7).

For total cholesterol, there were no significant differences by ethnicity, but gender differences were observed $\left(\mathrm{p}_{1}=0.00, \mathrm{p}_{2}=\right.$ 0.00 ) and the $95 \% \mathrm{CI}$ for the difference of the means was (-23.4; -5.8), with higher values for the F population than for the $\mathrm{M}$ population. This difference was particularly marked in the R population $\left(\mathrm{p}_{1}=0.01, \mathrm{p}_{2}=0.00\right)$ and the $95 \%$ CI for the difference of the means was $(-32.1 ;-6)$.

For HDL cholesterol, there was a significant difference between the sexes; the values for the $\mathrm{M}$ population were lower than for the F population $\left(\mathrm{p}_{1}=0.00, \mathrm{p}_{2}=0.00\right)$ and the $95 \%$ CI for the difference of the means was $(-9.4 ;-4.5)$. By ethnicity, too, differences were observed; $\mathrm{NR}$ was higher than $\mathrm{R}\left(\mathrm{p}_{1}=0.00, \mathrm{p}_{2}=0.00\right)$ and the $95 \%$ CI for the difference of the means was (4.47; 9.37). When compared by gender, among the $\mathrm{R}$ population, the value of this variable was lower among $\mathrm{M}$ than $\mathrm{F}\left(\mathrm{p}_{1}=0.00, \mathrm{p}_{2}=0.00\right)$ and the $95 \%$ CI for the difference of the means was $(-11 ;-5.2)$. Similarly, among the NR population, the corresponding value was also lower among the $\mathrm{M}$ population $\left(\mathrm{p}_{1}=0.03, \mathrm{p}_{2}=0.02\right)$ and the 95 $\% \mathrm{CI}$ for the difference of the means was $(-8.6 ;-1)$. By ethnicity, in the M population, HDL cholesterol was higher among M\&NR than $\operatorname{M} \& R\left(p_{1}=0.00, p_{2}=0.00\right)$ and the $95 \%$ CI for the difference of the means was $(5.3 ; 11.37)$, while among the F population, the 
value for F\&NR was higher than for F\&R $\left(\mathrm{p}_{1}=0.02, \mathrm{p}_{2}=0.01\right)$ and the $95 \% \mathrm{CI}$ for the difference of the means was $(1.4 ; 8.5)$.

For LDL cholesterol, there were significant differences by gender, with values for the $\mathrm{M}$ population being lower than those for $\mathrm{F}\left(\mathrm{p}_{1}=0.00, \mathrm{p}_{2}=0.00\right)$ and the $95 \% \mathrm{CI}$ for the difference of the means was $(-17.8 ;-3.8)$. In the $\mathrm{R}$ population, the value for M\&R was lower than that for $F \& R\left(p_{1}=0.01, p_{2}=0.01\right)$ and the $95 \%$ CI for the difference of the means was $(-24 ;-3.8)$.

With respect to triglycerides, we observed a very evident and significant difference by ethnicity. The value for the NR population was lower than that for $\mathrm{R}\left(\mathrm{p}_{1}=0.00, \mathrm{p}_{2}=0.00\right)$ and the 95 $\%$ CI for the difference of the means was $(-110.17 ;-41.86)$. This significant difference by ethnicity was also seen within each of the sexes; in the $M$ population, the value for $M \& N R$ was lower than for M\&R $\left(\mathrm{p}_{1}=0.02, \mathrm{p}_{2}=0.01\right)$ and the $95 \% \mathrm{CI}$ for the difference of the means was $(-148 ;-18)$ and among the F population, the value for $F \& N R$ was lower than for $F \& R\left(p_{1}=0.00\right.$, $\left.\mathrm{p}_{2}=0.00\right)$ and the $95 \% \mathrm{CI}$ for the difference of the means was $(-101 ;-34)$.

\section{Conclusions}

In this study, we have highlighted the features observed in the sample populations which the statistical analysis showed to be associated with ethnicity. Thus, the typical Gypsy patient was younger when T2DM was diagnosed and also younger when this study was conducted (2012). With respect to the patients' BMI, only $7 \%$ of our sample could be considered of normal weight. The typical Gypsy patient had a higher BMI than the non-Gypsy patient and, in particular, that of the female Gypsy patient was higher than that of the male Gypsy patient. Tobacco consumption was $50 \%$ more common among the Gypsy population. The sample population presented a high prevalence of arterial hypertension (75\%), and was higher among the Gypsy than the nonGypsy population. With respect to variables concerning vascular disease, the only clear and significant difference, by ethnicity, concerned complications affecting the lower limbs. This difference was very marked in the comparison between male non-Gypsy and male Gypsy patients.

Among the variables related to the degree of control of cardiovascular risk, we found significant differences between the Gypsy and non-Gypsy populations in the following variables: systolic blood pressure, diastolic blood pressure, HDL cholesterol, triglycerides and cardiovascular risk. In every case, the control was poorer among the Gypsy population.

\section{Strengths and limitations}

With respect to the study's limitations, we acknowledge the possibility of bias arising from misdiagnosis and under-reporting of risk factors, because some of the patients included in the study did not attend the health centre for the usual tests. However, both health centres have been operating for 30 years in the area, many of the GPs have been working there for many years, and the Diraya system has been installed and functional for over six years. Moreover, we were able to access to the prior database system, termed Tass, for any background information needed. This system had been functioning for over 20 years before Diraya came into operation. For all these reasons, we believe that the magnitude of the above-mentioned limitation is probably not significant.

With respect to information bias, we recognise the over-valuation of cardiovascular risk that is obtained by the Framingham index.

\section{References}

1. Ruiz-Ramos M, Escolar-Pujolar A, Mayoral-Sánchez E et al. La diabetes mellitus en España: mortalidad, prevalencia, incidencia, costes económicos y desigualdades. Gac Sanit.2006; 20 (Suppl 1): 15-24.

2. Hernán Prat M. Diabetes, síndrome metabólico y enfermedad cardiovascular. Cardiol Clín 2009; 25 (2): 61-65.

3. Mena FJ, Martín JC, Simal F, Carretero JL, Herreros V. Factores de riesgo cardiovascular en pacientes diabéticos. Estudio epidemiológico transversal en población general. Estudio Hortega. An Med Interna 2003; 20: 292-296.

4. Geert Goderis, MD et al. Monitoring modifiable cardiovascular risk in type 2 diabetes care in general practice. The use of an aggregated ZScore. Med Care 201; 48 (7).

5. Coffey R et al. A resource guide for state action. Rockville, MD: Agency for Healthcare Research and Quality; 2004.

6. Bosch X, Alfonso F, Bermejo J. Diabetes y enfermedad cardiovascular. Una mirada hacia la nueva epidemia del siglo XXI. Rev Esp Cardiol 2002; 55 (5): 525-527.

7. Sánchez-Recalde A, Kaski JC. Diabetes mellitus, inflamación y ateroesclerosis coronaria: perspectiva actual y futura. Rev Esp Cardiol 2001; 54: 751-763.

8. Martínez-González J, Llorente-Cortés V, Badimon L. Biología celular y molecular de las lesiones ateroescleróticas. Rev Esp Cardiol 2001; 54: 218-231.

9. Vinagre I, Mata-Cases M, Hermosilla E et al. Control of glycemia and cardiovascular risk factors in patients with type 2 diabetes in Primary Care in Catalonia (Spain). Diabet Care 2005; 35: 774-779.

10. Laakso M. Hyperglycemia and cardiovascular disease in type 2 diabetes. Diabetes 1999; 48: 937-942.

11. Kirsten J, Copell et al. Progression of glycaemia and cardiovascular risk factors in patients of different age groups with new type 2 diabetes over 5 years of follow-up in a diabetes quality improvement initiative. Diabet Res Clin Pract 2011; 93: 357-362.

12. Copell K, McBride K, Williams S. Under-reporting of diabetes on death certificates amog a population with diabetes in Otago Province. New Zealand. N Z Med J 2004; 117 (1207): U1217.

13. Roper NA, Bilous RW, Kelly WF, Unwin NC, Connolly VM. South Tees Diabetes Mortality Study: Cause-specific mortality in a population with diabetes: South Tees diabetes mortality study. Diabet Care 2002; 25: 43-48.

14. Connolly V, Unwin N, Sheriff P et al. Diabetes prevalence and socioeconomic status: a population based study showing increased prevalence of type 2 diabetes mellitus in deprived areas. J Epidemiol Community Health 2000; 54: 173-177. 


\section{$579-584$}

15. Riste L, Khan F, Chruickshank K. High prevalence of type 2 diabetes in all ethnic groups, including Europeans in a British inner city. Diabet Care 2001; 24: 1377-1383.

16. Larrañaga I, Arteagoitia JM, Rodríguez JL et al. Red de Médicos Vigía. Desigualdades socioeconómicas en pacientes diabéticos tipo 2. CAPV. Seminario RCESP Políticas de Salud y Desigualdades. Barcelona. 18 febrero 2005. (Documento mimeografiado).

17. Beljic-Zivkovic T, Marjanovic M, Prgomelja S et al. Screening for diabetes among Gypsy people living in Serbia. Croat Med J 2010; 51: 144-150.

18. Vozarova De Courten B, De Courten M, Hanson RL, Zahorakova A, Egyenes HP, Tataranni PA et al. Higher prevalence of type 2 diabetes, metabolic syndrome and cardiovascular diseases in gypsies than in nongypsies in Slovakia. Diabet Res Clin Pract 2003; 62 (2): 95-103.

19. Dolinska S, Kudlackova M, Ginter E. The prevalence of female obesity in the world and in Slovak gypsy women. Bratisl Lek Listy 2007; 108 (4-5): 207-211.

20. Krajcovicova-Kudlackova M, Blazicek P, Spustova V, Valachovicova M, Ginter E. Cardiovascular risk factors in a young Gypsy population. Bratisl Lek Listy 2004; 105 (7-8): 256-259.
21. Hujová Z, Alberty R, Ahlers I et al. Cardiovascular risk predictors in Central Slovakian Gypsy children and adolescents: regional differences. Cent Eur J Public Health. 2010; 18 (3): 139-144.

22. Valachovicova M, Krajcovicova-Kudlackova M, Spustova V, Blazicek P, Madaric A, Ginter E. Cardiovascular risk markers in gypsy population of Slovakia. Bratisl Lek Listy 2004; 105 (7-8): 256-259.

23. Thomas JD, Doucette MM, Thomas DC, Stoeckle JD. Disease, lifestyle, and consanguinity in 58 American Gypsies. Lancet 1987; 2 (8555): 377-379.

24. La situación de multidiscriminación ante el empleo en personas de etnia gitana con discapacidad. Fundación ONCE. Programa Operativo de Lucha contra la Discriminación 2000-2006.

25. García C. Guía para la actuación con la comunidad Gitana en los Servicios Sanitarios. Fundación secretariado gitano.

26. Simko V, Ginter E. Short life expectancy and metabolic syndrome in Gypsynies (gypsies) in Slovakia. Cent Eur J Publ Health 2009; 18 (1): 16-18.

Received June 18, 2013. Accepted May 25, 2014. 